\title{
The Police, the Immigration Office and Illegal Immigrants: Indonesian's Cases
}

\author{
Muradi $^{1}$ \\ ${ }^{1}$ Department of Government, Faculty of Social and Political Sciences, University of Padjadjaran, Bandung, \\ Indonesia \\ Correspondence: Muradi, Department of Government, Faculty of Social and Political Sciences, University of \\ Padjadjaran, Bandung, Indonesia. E-mail: muradi_clark@unpad.ac.id
}

Received: May 7, 2015 Accepted: June 27, 2015 Online Published: August 24, 2015

doi:10.5539/jpl.v8n3p127 URL: http://dx.doi.org/10.5539/jpl.v8n3p127

\begin{abstract}
As a country that has strategic position, Indonesia faces illegal trafficking of people and goods. If the illegal traffic is not taken seriously, not only the country will lose revenue from customs duties, but also not integrated efforts against illegal traffic of goods and people. This paper will discuss the role of POLRI in assisting the Immigration Office in combating human trafficking and smuggling. This paper will also discuss the problem of illegal immigrants and human trafficking is complicated due to unscrupulous government and security apparatus. This paper also seeks actors involved and their role in paving the way for illegal immigrants. Finally, this paper argue the duty of POLRI in assisting the Immigration Office will run effectively if it involves a number of government agencies relating to the management and supervision of foreign territories, including the Ministry of Home Affair and the Armed Forces (TNI).
\end{abstract}

Keywords: the police, the immigration office, illegal immigrants, the armed forces

\section{Introduction}

As a country lies in a strategic position, Indonesia faces so many illegal trafficking of people and goods. If the illegal traffic is not taken seriously, not only the country will lose revenue from customs duties, but also not integrated efforts against illegal traffic of goods and people. Specifically on the traffic, The Immigration Office is the main component in the international traffic management from and to Indonesia. However, in the context of combating illegal immigrants, The Immigration Office cannot work alone. This is because illegal immigrants and smuggling has given profits for some people, as human trafficking involves many parties and networking. Human trafficking network starts from the origin country, transit countries like Indonesia, and destination countries, Australia.

The role and function of the Immigration Office, based on Law No. 6/2011 on Immigration, has limited administrative function at the border crossing and immigration checkpoints. It is certainly not enough to eradicate human trafficking network, in which allegedly also involved unscrupulous government officials, both from the security institutions and other government actors, like local governments.

The Indonesia National Police (POLRI) as one of the government institution, have a role in the maintenance of security and public order, law enforcement, protection, sheltering, and services to the community in order to maintain Internal Security (Kamdagri). Specifically on combating human trafficking, the police have a duty to supervise the functional police against foreigners.

Coordination in Indonesia with relevant agencies as stipulated in Law no. 2/2002 on Police Article 15 Paragraph 2 , point $\mathrm{i}$ on monitoring foreigners who have no documents are gradually law enforcement function related to the handling of illegal immigration and smuggling. Coordination with related institutions is manifested in a number of cooperation agreements between the police with the Ministry of Justice and Human Rights, in particular the Immigration Office. The cooperation agreement is on restrictive functions of each agency in the field. In terms of law enforcement, The POLRI is a major component. Conversely, when it comes about immigration documents, the Immigration Office is the one to do so. In addition, more coordination at the operational level in handling cartel or group that organized human trafficking to Australia who makes Indonesia as a transit country, and also from Indonesia to neighboring countries with the same purpose. 
This paper will discuss the role of POLRI in assisting the Immigration Office in combating human trafficking and smuggling. This paper will also discuss the problem of illegal immigrants and human trafficking is complicated due to unscrupulous government and security apparatus. This paper also seeks actors involved and their role in paving the way for illegal immigrants. Finally, this paper argue the duty of POLRI in assisting the Immigration Office will run effectively if it involves a number of government agencies relating to the management and supervision of foreign territories, including the Ministry of Home Affair and the Armed Forces (TNI).

\section{Handling Illegal Immigrants and Its Problems}

The Immigration Office is aware the strategic position of Indonesia and its implications for the tasks and role of immigration as a whole. In the context of the immigration Office, the intensity of the arrival of illegal activities and the presence of Indonesia as a transit country to Australia increase instability. In the cold war era, refugees made Indonesia as a transit country due to political instability in their origin country or the rivalry of two great ideologies. ${ }^{1}$ So in the post-cold war, refugees who make Indonesia as a transit country before crossing into Australia is based on desire to find a better life. Post-Cold War political reason is used by some minority groups in a number of troubled countries in the Middle East, Afghanistan, Iraq, Iran or Myanmar. ${ }^{2}$

Beside the issue of illegal immigrants, immigration in Indonesia post-New Order faced problem of human trafficking from and to Indonesia based on commercial human slavery at work, illegally, in neighboring countries. Jobs offered are working on plantations, restaurant waiters, and to become a prostitute. In the context of human trafficking, The Immigration Office has limitation on cross-border management and immigration administration. So that administrative processes is at crossing border of neighboring countries, assuming that the administrative immigration is not abused for the sake of illegal employment in Indonesia and destination countries. $^{3}$

Another issue related to immigration is rampant acts of terrorism as impact of less stringent immigration procedures in Indonesia. ${ }^{4}$ Terrorists allegedly using less stringent immigration procedures so that they can leave and enter the Philippines or Pakistan and Afghanistan for training bomb-making skills to conduct terror acts in Indonesia ${ }^{5}$.

Hikmawanto asserts five reasons why Indonesia is a transit country to Australia, namely: First, the position of Indonesia and Australia although separated by a wide ocean. Second, the extent of Indonesia Sea Territory can be easy penetrated by illegal immigrants. Many of them do not pass through Immigration Check Point (FAP) at ports and airports. The Navy and the POLRI are not sufficient to guard a wide sea area against illegal immigrants. Third, if they enter through official channels, there are local officials who can pass them with a certain amount of money. Fourth, In Indonesia it must be admitted that, there are mafia facilitating illegal immigrants from some countries in the Middle East to get to Australia. And fifth, the fishermen and sailors who dared to carry improvised boats for illegal immigrants with financial compensation. ${ }^{6}$

\footnotetext{
${ }^{1}$ For example, see Ditjenim (2005). Sejarah Imigrasi Indonesia. Jakarta: Direktorat Jenderal Imigrasi. See also The Express Tribune. (2012). "Five Million Illegal Immigrant Residing in Pakistan" [online available]: http://tribune.com.pk/story/322325/five-million-illegal-immigrants-residing-in-pakistan/ (accessed April, 13 $\left.{ }^{\text {th }} 2015\right)$.

2 For example, see Kompas. (2012). “Alasan Imigran Timur Tengah Kabur ke Australia”. [online available]: http://regional.kompas.com/read/2012/10/25/16354133/Alasan.Imigran.Timur.Tengah.Kabur.ke.Australia (accessed April, 13th 2015).

3 See Matatelinga. (2015). "BNP2TKI dan Imigrasi Perketat Calon TKI" [online available]: http://matatelinga.com/index.php?option=com_content\&view=article\&id=8048:bnp2tki-dan-imigrasi-perketat-calon-tki\&catid=30:daerah\&It emid=37 (accessed April, 13 ${ }^{\text {th }}$ 2015). See also. PekanbaruMX. (2009). "Imigrasi Perketat ADM Imigrasi Paspor". [online available]: http://pekanbarumx.net/content/view/793/37/ (accessed April, 13 ${ }^{\text {th }}$ 2015).

4 Muslim Daily. (2010). "Polisi Wanti-wanti Ancaman Terorisme Dibalik Masalah Imigran Gelap". [online available]: http://muslimdaily.net/berita/lokal/polisi-wanti-wanti-ancaman-terorisme-dibalik-masalah-imigran-gelap.html\#.UU61wphpsb0 (accessed March 12 $2^{\text {th }}$ 2015). See also, Suara Indonesia. (2012). "Polri Waspadai Potensi Terorisme 2013". [online available]: http://suaraindonesia.co/nasional/4776/polri-waspadai-potensi-terorisme-2013 (accessed March 12th 2015). See also The Jakarta Post. (2015). "Australia Sends Illegal Immigrants Back RI Territory". [online available]: http://www.thejakartapost.com/news/2015/03/23/australia-sends-illegal-immigrants-back-ri-territory.html (accessed May 2nd 2015).

5 Waspada. (2012). "Imigran Gelap Afganistan Harus Diwaspadai". [online available]: http://www.waspada.co.id/index.php?option=com_content\&view=article\&id=260617:imigran-gelap-afganistan-harus-diwaspadai\&catid=14: medan\&Itemid=27 (accessed march $12^{\text {th }}$ 2015). See also Gunaratna, Rohan. (2002). Inside Al Qaeda: Global Network of Terror. New York: Columbia University Press. Especially in Chapter One.

6 DetikNews. (2011). "5 Alasan Indonesia Menjadi Surga Transit Imigran Gelap ke Australia". [online available]: http://news.detik.com/read/2011/12/20/182116/1795871/10/5-alasan-indonesia-jadi-surga-transit-imigran-gelap-ke-australia (accessed March 11th 2015).
} 
However, Hikmawanto does not describe how society and government also take advantage of the proliferation of illegal immigrants in Indonesia. The last ten years, for example, the area of Cisarua, Bogor West Java, changed their appearance of being 'Arab village', because so many local people who get married, unregistered and contracted, with a number of foreigners from the Middle East while he is together with his extended family. ${ }^{7}$

However, based on several studies and investigations from media and academic circles, these middle east foreigners are not entirely out of the Middle East, but also from Iraq, Turkey, Afghanistan, Pakistan, Iran, and so on, both as tourists, refugees, and illegal immigrants, because some area in Cisarua is used as shelter for illegal immigrants and refugees by UNHCR. ${ }^{8}$ In the "Arab village", Cisarua, it is easy to get new identity, using temporary ID card, or other document for the wedding. The "Siri Marriage" or "Contracted Marriage" needs a number of documents required in order to facilitate the marriage process. ${ }^{9}$

Beside Cisarua, there is also Garut who become target for illegal immigrants. It is different from the Arab village in Cisarua, Garut is more diffuse with the local community, making it difficult to distinguish them from the general public. Garut has become target for temporary settlement, because through Rancabuaya, South Garut, they can cross the ocean to Australia.

Arab village in Cisarua and Rancabuaya, South Garut, in West Java are examples of how easy to get in Indonesia and settled down before finally cross into Australia illegally. This cannot happen if it is not supported by the permissive attitude of local residents and government actors who sustain their existence. There are five elements that take advantage of government agencies and pave the foreigners and illegal immigrants to reside temporarily and even married a contract with the local residents, namely: First, local community leader who usually becomes the RT or RW Chairman of the local authority which has issued temporary residence permits to foreign nationals and illegal immigrants in the area. Usually because of the proximity and the motive to make profits, the foreign residents get temporary ID card to settle permanently and marrying locals. Community leaders, when not serving as Chairman of RT/RW, can recommend relatives to obtain a residence permit to the local RT and RW. Even on a certain degree of daring guarantee the foreigners and illegal immigrants to become citizens of the local registered. As long as there are people who are known to guarantee and incorporate other people into the Card family, the RT and RW can proceed to obtain a permanent ID card.

Residence registration is a reproach to foreign nationals and illegal immigrants to obtain population administration in Indonesia before crossing to Australia. There is a belief in a number of foreign nationals and illegal immigrants, it will be easier to use the passport administration of Indonesian immigration as the country of origin if they want to go to Australia, both legal or illegal. There are many foreigners and illegal immigrants who do not have the patience to wait for becoming Indonesian citizen in order to have passport. No wonder then, they take a shortcut by making mere transit before entering Indonesia illegally to Australia can be said to be massive.

Second, local government actors, particularly Lurah and Camat (Local Administration Chairman) who consciously or unconsciously legalize population administration, both ID Card and Family Card (KK) proposed by local RT and RW. As in the context of bureaucracy, these legalities provide benefits for local officials. In addition to the provision of population administration, a number of unscrupulous government also often helped illegal immigrants who want a quick way to cross into Australia through the South Coast and South of Garut and Cianjur. ${ }^{10}$ The Immigration Ofiice also put on list Sukabumi, Tasikmalaya, both in West Java Province and Kupang, East Nusa Tenggara Province as entrance of illegal immigrants to Australia. Special to Kupang, the distance to the Australian territory is just 24 hours away by fishermen boats. ${ }^{11}$

Third, the involvements of corrupt officials of Immigration Office in the process of immigration document issues.

\footnotetext{
7 See Pos Kota News. (2012). "Selain Maroko di Puncak Ada Pelacur dari Bahrain dan Mesir". [online available]: http://www.poskotanews.com/2012/07/03/selain-maroko-di-puncak-ada-pelacur-dari-bahrain-dan-mesir/ (accessed March 11 ${ }^{\text {th }}$ 2015). DetikNews. (2006). "Mafia Kawin Kontrak di Puncak: Mimpi Melati di Kampung Arab". [online available]: http://news.detik.com/read/2006/07/13/100616/634805/159/mimpi-melati-di-kampung-arab (accessed march 11th 2015).

8 Faithfreedom.org. (2012). "Warga Cisarua Ultimatum Imigran Segera Angkat Kaki". [online available]: http://indonesia.faithfreedom.org/forum/akhlak-mulia-para-imigran-gelap-di-cisarua-t50242/ (accessed March, 11 ${ }^{\text {th }} 2015$ ).

9 Kompas. (2011). "Kawin Kontrak Dibenci Tapi Juga Disukai". [online available]: http://megapolitan.kompas.com/read/2011/07/04/10381071/Kawin.Kontrak.Dibenci.Tapi.Juga.Disukai (accessed March 12th 2015).

10 Antara Jawa Barat (2012). "Polres Cianjur Belum Tahun Ratusan Imigran Lolos". [online available]: http://www.antarajawabarat.com/lihat/berita/40649/polres-cianjur-belum-tahu-ratusan-imigran-lolos (accessed March, 12th 2013).

11 Tempo. "Tiga Pintu Masuk Imigran Gelap ke Australia". [online available]: http://www.tempo.co/read/news/2011/12/13/058371516/Tiga-Pintu-Masuk-Imigran-Gelap-ke-Australia (accessed March, 12th 2015).
} 
Immigration document can be processed if the illegal immigrants had residence documents obtained from the help of two points above, individual community leaders and local government. However, this method is not very much in demand by the illegal immigrants who risk their lives just to get to Australia, rather than using legal means to document immigration from Indonesia.

In addition, unscrupulous immigration officials are often easily bribed by illegal immigrants in order to escape from 13 of Immigration Detention Center (Rudenim) spread over in a number of regions in Indonesia ${ }^{12}$, or just out a few hours of Rudenim to enjoy the city where Rudenim is located. As the character of the bureaucracy in Indonesia, the unscrupulous Immigration officials are also easy to control with bribe them with some money, in fact rarely also squeeze to profit from illegal immigrants and its troubled. ${ }^{13}$

Fourth, individual POLRI involved in passing illegal immigrants to cross into Australia. A high-ranking Agency, ranked AKBP (lieutenant colonel), from the Directorate of Security Intelligence of West Nusa Tenggara Police Office arrested illegal immigrant backings when they attempt to cross into Australia. ${ }^{14}$ The arrest of middle rank police officer becomes a signaled that in the area closely to Australia, some rogue police officers in that areas have potentially to take advantage of illegal immigrants who want to continue the journey to Australia. Although, in other areas too, the involvement of individual members of the police were backing illegal immigrants are still occur, for example, in the District of Baubau, Southeast Sulawesi, there are unscrupulous members of the Police Chief Brigadier rank (Bripka), which became the guardian of dozens of illegal immigrants from Myanmar bound for Australia. ${ }^{15}$

Fifth, the involvement of members of the TNI in paving the way for illegal immigrant to continue their journey to Australia. The involvement of individual members of the TNI has been mostly a bodyguard of a group of illegal immigrants who want to sail to Australia. ${ }^{16}$ In Sukabumi for example, there are five military personnel of Kodam III Siliwangi escorting four mini buses containing dozens of illegal immigrants who will use the path Sukabumi to sail to Australia. Also in Madison, East Java, a person caught in the TNI is preparing to deliver a group of illegal immigrants from the Middle East to be pointing the way across to Australia for a fee of Rp. 10 Million (A \$ 10,000) through the South coast of East Java. ${ }^{17}$

Aside of five people of institutional and non-institutional, community involvement in helping illegal immigrants is also fairly massive. At least, based on the record Desk Handling of People Smuggling, Refugees and Asylum Seekers (P2MP2S) Coordinating Ministry for Political, Legal and Security, there are 514 fishermen and boat crews who were undergoing punishment in Australia as it helps take across illegal immigrants, of which 26 of them are children ${ }^{18}$. Benefits received by the fishermen and the crew is relatively lucrative income when compared to fishing, return around Rp. 50 million to Rp. 75 million (A $\$ 50,000-75,000$ ) once delivery, although the risk is obtained arrests for entry into Australian sea territory illegally and carrying illegal immigrants.

Based on above context, the problem of handling illegal immigrants in Indonesia until now is hard to do. This is due to the many interests that take advantage of the opportunity for personal gain. There are three affirmations attached thereto namely: First, the issue of illegal immigration has not been a threat to national security and

12 More information for Detention Centre of Indonesia's Immigration Office, see the link: http://www.imigrasi.go.id/index.php/hubungi-kami/rumah-detensi-imigrasi

${ }^{13}$ Detik Surabaya. (2011). "Bantu Imigran Gelap, Kanwil Depkumham Janji Telusuri Keterlibatan Oknum Imigrasi”. [online available]: http://surabaya.detik.com/read/2011/12/23/122339/1798374/475/kanwil-depkumham-janji-telusuri-keterlibatan-oknum-imigrasi (accessed march, 29th 2015). See also Pos Kupang. (2010). "Kepala Rudenim Kupang Mengaku Lalai. [online available]: http://kupang.tribunnews.com/2010/10/12/kepala-rudenim-kupang-mengaku-lalai. (accessed March, 30th 2015). Centroone. "Peras WNA, Dua Pegawai Imigrasi Dibui". [online available]: http://www.centroone.com/news/2011/10/2y/peras-wna-dua-pegawai-imigrasi-dibui/ (accessed March, 29 ${ }^{\text {th }}$ 2015).

14 DetikNews. (2012). "Polisi Berpangkat AKBP Ditangkap Terkait Penyelundupan Imigran ke Australia". [online available]: http://news.detik.com/read/2012/06/04/100053/1931783/10/polisi-berpangkat-akbp-ditangkap-terkait-penyelundupan-imigran-ke-australia?n d771104bcj (accessed March $11^{\text {th }}$ 2015)

15 JPNN. (2012). "Lindungi Imigran Gelap, Oknum Polisi Jadi Tersangka". [online available]: http://www.jpnn.com/read/2011/02/01/83440/index.php?mib=berita.detail\&id=125688 (accessed March $12^{\text {th }} 2015$ )

${ }^{16}$ Radar Bogor. (July, 19 $\left.{ }^{\text {th }} 2012\right)$. "Kawal Imigran Puncak, Lima TNI Ditangkap".

17 Tribun Timur. (2012) "Pandu Imigran Gelap Oknum TNI Dibayar Rp. 10 Juta". [online available]: http://makassar.tribunnews.com/2012/09/03/pandu-imigran-gelapoknum-tni-dibayar-rp-10-juta (accesses 23rd 2015). Tempo. (2012). "Selundupkan Imigran, Oknum TNI Dapat Ratusan Juta". [online available]: http://www.tempo.co/read/news/2012/09/12/063428961/Selundupkan-Imigran-Oknum-TNI-Dapat-Ratusan-Juta (accessed March 30, 2015).

${ }^{18}$ Kementerian Koordinator Politik, Hukum, dan Keamanan. (2012). "Desk P2MP2S Akan Berusaha Bebaskan 26 Tahanan Anak Dibawah Umur Dalam Kasus Penyelundupan Imigran Gelap di Australia “. [online available]: http://www.polkam.go.id/Beranda/tabid/38/mid/394/newsid394/250/language/en-US/Default.aspx (accessed March 30th 2015). 
sovereignty, because the border crossers are only making Indonesia as a transit point before crossing to Australia. This particular situation makes the institution related directly or not directly related to not feeling makes the problem of illegal immigrants as a priority issue. Although at the Coordinating Ministry for Political, Legal and Security has established Desk Handling People Smuggling, Refugees and Asylum Seekers (P2MP2S), but the function of the desk are more illegal immigrants and mediate issues of human smuggling cases involving citizens of Indonesia, both in Australia and other countries is the goal of Indonesian citizens to work abroad illegally.

Second, because there is not a threat to national security and sovereignty of the state, the handling of illegal immigrants are not shaded by the political policies that can bind to relevant state institutions and not directly related. Policy is at least level assigned Regulation handling illegal immigrants in a number of state institutions such as the Immigration Office that has the function of immigration and cross-border, Ministry of Internal Affairs has the record function of population, as well as POLRI and military on the function of Homeland Security and National Defense. No wonder because there is no policy that binds to a number of institutions mentioned above, then each institution has not looked at the importance of handling illegal immigrants in their respective institutions.

Third, a derivative to the second point, the handling of illegal immigrants is not in integral scheme between the Immigration Office, the POLRI, the TNI, and also the Ministry of the Internal Affairs. The Immigration Office handles illegal immigrants separate ways and not integrated with other institutions. The involvement of the police, the military, and also Ministry of Internal Affairs are more than just supporting, which in certain circumstances would reduce backfire against the Immigration Office due to violation of law because illegal immigrants are trying to escape and bribe corrupt officials Immigration, asking for escort to TNI and POLRI personnel, where a fishing boat has been waiting to carry illegal immigrants headed to Australia.

\section{Police Support}

Problems of illegal immigrants, as described above, will only be made if from the outset the government considers illegal immigrants as a threat to national security and sovereignty. Because, without it, then each institution, both the Office of Immigration and other institutions such as the POLRI just assume as part of the roles and functions attached to each of its members, which will only feel involved when it became part of the roles and functions itself. For example, the POLRI will only directly involved in the handling of illegal immigrants if the illegal immigrants had been unsettling and threatening security and order, and homeland security. The excess of the problem of illegal immigrants by the POLRI through the Detachment 88 AT (Densus $88 \mathrm{AT}$ ) and National Agency for Counter-Terrorism (BNPT) is strengthening the existence of terrorist organizations in Indonesia, Directorate of Anti-Narcotics, Criminal Investigation Board of POLRI e and the National Anti-Narcotic Agency (BNN) is a narcotic that use illegal immigrants as its courier.

However, the POLRI as one of the actual functions of state government has explicitly stated that the POLRI conduct functional police surveillance against foreigners in the territory of Indonesia in coordination with relevant agencies, as well as Article 15 Paragraph 2, point i, Law no. 2/2002 on the POLRI. Relevant agencies were also ablaze leads the Immigration Ofice in the Ministry of Justice and Human Rights. Even in Article 15 Paragraph 3 of Law No. 2/2002 would require the legal level of Government Regulation in the handling of foreigners within which is the problem of illegal immigrants.

Since 2007, the POLRI, International Organization of Migration (IOM,) conducted a variety of training and strengthening understanding and operating in handling illegal immigrants by the POLRI, which involves three entities and the divisions that exist in the POLRI Headquarters, namely: Security Intelligence Agency (Baintelkam), especially the Directorate of State Security, Security Maintenance Agency (Baharkam), particularly in the Directorate Guidance Society (Bimmas), Maritime Police Directorate, and the Directorate of the Air Police, and the Criminal Investigation Agency (Bareskrim), particularly the Directorate of Anti-Narcotics, and International Relations Division, in particular the Secretariat NCB/Interpol. However, the training explicitly intended to strengthen the role of the POLRI in handling security in the context of illegal immigrants in the country. Thus, the task of handling illegal immigrants with limited immigration Office in coordination with the restriction roles and functions of each institution. No wonder then if the training was initiated by IOM only on strengthening the understanding of the POLRI in handling the anticipated negative effects of illegal immigration, not the handling of illegal immigrants are integral to the Immigration Office.

The efforts made by the IOM to strengthen understanding and operational problems of illegal immigrants on the legality of the POLRI because there was a barrier between the functioning of the POLRI with immigration Office functions. It is recognized correctly by the IOM when seeing Law No. 2/2002 on POLRI and Law No. $6 / 2011$ on Immigration, which one describe the function of Immigration Office as independent investigation 
which can process all immigration issues without having to involve the POLRI. At that point essentially support of POLRI on the handling of illegal immigrants is not very clear.

Ambiguity exists in policing functions, which are also attached to the Immigration Office. Thus, if there is even the POLRI support task associated with the handling of illegal immigrants more because of the effect of the presence of illegal immigrants themselves are not in the settlement, as was done by the Bareskrim of POLRI and the Office of Immigration on the handling of drug smuggling who use illegal immigrants as intermediaries and couriers. ${ }^{19}$ The interesting thing is precisely the counter terrorism, there is no cooperation in writing as in narcotics eradication. This situation would require assertions that the POLRI perspective, especially Densus 88 AT and BNPT that illegal immigrants have the potential for increased radicalization that lead to terrorism. ${ }^{20}$

Different interests and perspectives in seeing illegal immigrants between the POLRI and the Immigration Office are understandable given the constraints and corridors roles and functions of each institution has not been fully integrated. Gray area that should be undertaken together between the POLRI and the Immigration Office became crucial point violations and actions taken advantage of corrupt immigration officials and police and other enforcement agencies such as the military in the handling of illegal immigrants. The gray area in which arrests of illegal immigrants, sending illegal immigrants to Immigration Detention House (Rudenim), supervision and maintenance of illegal immigrants in Rudenim, escort the deportation of illegal immigrants and or shipment to third countries, to the involvement of organizations such as IOM and UNHCR that do not involve the police and other institutions in the process.

In the context of cooperation, it was not built in a similar position, because the function of immigration is more powerful than the police function. So that in the context of handling illegal immigrants, the police do the supporting job, except in the case of drugs and terrorism, which the police can take control of management initiatives such cases.

There are four stages of assistance tasks that can be done by the police relating to the handling of illegal immigrants by the Immigration Office, namely: First, the stage of monitoring the movement of illegal immigrants will go to Indonesia. The POLRI at this stage to activate the role of Interpol and Police Attaché or Liaison Officer of Police or equivalent is usually located under the same roof with the Defense Attaché Indonesian representatives in several countries, particularly many of the residents chose to seek a new and better life as the Middle Eastern countries, Iraq, Iran, Pakistan, Afghanistan, Sri Lanka, Vietnam, Cambodia, and so forth.

In addition, the involvement of Interpol is also intended to unravel organized international shipments of illegal immigrants to Australia who make Indonesia as a transit country. Organized networks are not just sending illegal immigrants to Indonesia, but also drugs and radicalism which of concern to police. During this international network that organizes shipments of illegal immigrants has been building networks in Indonesia. ${ }^{21}$ Thus, sooner or later it would threaten the existence of the network not only national security and sovereignty of the state, but also threaten the people of Indonesia, bringing with them a radical ideology and narcotics.

Second, tightening sea patrols by the Maritime Police and the Navy in a traditional path to enter Indonesia illegally, especially along the Straits of Malacca, the Sunda Strait, the waters of Natuna Islands, and harbor illegal scattered in some other areas. ${ }^{22}$ This step is to close in and the mixed illegal immigrants with the general public. Therefore, religion and kinship approach can obscure the identities of the illegal immigrants are from pursuit by the security forces. During this difficulty Immigration and security is one of them because the local people are actively involved in the obscure and hide information illegal immigrants with a variety of motives, but money is a problem in common religious identity.

Third, intensive supervision related to the presence of strangers by the Police Directorate of State Security,

\footnotetext{
19 Vivanews. (2012). "Kasus Narkoba Warga Asing, Bareskrim Gandeng Imigrasi”. [online available]: http://nasional.news.viva.co.id/news/read/367161-kasus-narkoba-warga-asing--bareskrim-gandeng-imigrasi (accessed March 312015 ). Skalanews. (2012). "Imigrasi dan Mabes Polri Bikin Kerjasama Penanggulangan Narkoba". [online available]: http://skalanews.com/news/detail/128953/4/imigrasi-dan-mabes-polri-bikin-kerjasama-penanggulangan-narkoba.html (accessed March 31, 2015).

$20 \quad$ Kalteng Pos. (2012). “Antisipasi Terorisme Awasi Orang Asing!”. [online available]: http://www.kaltengpos.web.id/?menu=detail_atas\&idm=12150 (accessed march, 31 2015).

21 For example, see Antara News. (2009). "Enam WNI Diduga Terlibat Jaringan Imigran Gelap”. [online available]: http://www.antaranews.com/berita/1255273846/enam-wni-diduga-terlibat-jaringan-imigran-gelap (accessed March 31st 2015).

22 Bisnis Kepri. (2012). "Polda Kepri Ungkap Jaringan Baru Penyelundupan manusia". [online available]: http://www.bisnis-kepri.com/index.php/2012/04/polda-kepri-ungkap-jaringan-baru-penyelundupan-manusia/ (accessed march 31th 2015).
} 
Baintelkam, and Bimmas, Baharkam POLRI. The POLRI should always be informed by the Immigration Office regarding entry and exit of foreigners to Indonesia than to get themself through the police network Interpol and Police Attaché and Indonesian representatives abroad. The Intensive supervision of foreigners who will provide positive stimulation for the limited space for illegal immigrants networks in Indonesia. It also means that the involvement of unscrupulous immigration officials and security elements, both military and police would itself limited.

Fourth, the involvement of communities and local government in Community Policing program organised by the POLRI to maintain conducive environment. The program is also integral to the existence the TNI Territorial Command of Babinsa can be partners in minimizing the space and the presence of illegal immigrants which conducted independently by the people themselves. Besides stimulating community involvement is also limited space for terrorist networks and drug abuse is also a concern that the POLRI were allegedly often a part of being an illegal immigrant.

These four stages should be highlighted more effective if it is supported by the presence of at least of government regulation. And it should also involve other institutions such as the Ministry of Internal Affairs and the military. Therefore, the POLRI task may also be supported by other institutions will only be effective if they are hand in hand to confirm that the illegal immigrants problem is part of their role and main functions. Legal aspect is also on how the government is related to the handling of illegal immigrants. Because, as long as the government still sees illegal immigrants not as a threat to state sovereignty and national security, so long as it is also the handling of illegal immigrants would only be a ground for rogue elements both community leaders, and state agencies to obtain economic benefits as an explanation at the beginning.

\section{Conclusion}

Handling illegal immigrants in Indonesia can only be done with the integral approach, which is not only done by the Office of Immigration but involve other state institutions such as the Police, Army and Ministry of Internal Affairs. Besides handling illegal immigrants should also actively involve the community in anticipation of the process of assimilation to bring religious sentiments and reasons economic benefits.

Involving the handling of illegal immigrants, POLRI supports apparently can not just run the main roles and functions of each. Different interests and sliced roles and functions both also involve other institutions such as the military and the Interior Ministry. Moreover, obstacles challenges in handling illegal immigrants there are contributions from the individuals not only police, but also the military and Ministry of Internal Affairs through local government.

Addition of no less significance is the handling of illegal immigrants would be more effective and integral if supported by the legality of the government at least equivalent to synergize Regulation institutions in it, both the Office of Immigration, the POLRI, the TNI and Ministry of Internal Affairs. Government regulations are in addition ensures the Indonesian government's commitment related to the handling of illegal immigrants, government regulation is a form of coercion to the institution to establish coordination of assistance, to the joint operations in the handling of illegal immigrants, during which it almost never happened.

\section{References}

Bailey, J., \& Dammert, L. (Eds.). (2006). Public Security and Police Reform in the Americas. Pittsburgh: University Pittsburgh Press.

Djamin, A. (2005). Masalah dan Issue Manajemen Kepolisian Negara RI dalam Era Reformasi. Jakarta: Yayasan Brata Bhakti Polri.

Djamin, A. (2006). Sejarah Perkembangan Kepolisian di Indonesia: Dari Zaman Kuno Sampai Sekarang. Jakarta:Yayasan Brata Bhakti Polri.

Gunaratna, R. (2002). Inside Al Qaeda: Global Network of Terror. New York: Columbia University.

Hauptman, S. (2013). The Criminalization of Immigration The Post 9/11 Moral Panic. Washington DC: LFB Scholarly Publishing.

Hayworth, J. D. (2005). Whatever It Takes: Illegal Immigration, Border Security, and the War on Terror. Washington DC: Regnery Publishing.

Hoffmaster, D. A. et al. (2010). Police and Immigration: How Chiefs Are Leading their Communities through the Challenges. Washngton DC: Police Executive Research Forum.

Newton, L. (2008). Illegal, Alien, or Immigrant: the Politics of Immigrant Reform. New York: New York 
University Press.

Seghetti, L. M. (2009). Enforcing Immigration Law: The Role of State and Local Law Enforcement. Washington DC: Congressional Research Centre.

\section{Copyrights}

Copyright for this article is retained by the author(s), with first publication rights granted to the journal.

This is an open-access article distributed under the terms and conditions of the Creative Commons Attribution license (http://creativecommons.org/licenses/by/3.0/). 